\title{
ANALISIS EKUITAS MEREK GULA PASIR GULAKU DAN GUPALAS
}

\author{
Darul Bakhtiar ${ }^{\mathrm{a}}$ \\ Sri Wahyuni Astuti \\ ${ }^{a}$ Sekolah Pascasarjana Universitas Airlangga ${ }^{b}$ Fakultas Ekonomi dan Bisnis Universitas Airlangga \\ Email:darul.bahktiar@gmail.com ${ }^{a}$; astutisriwahyuni13@gmail.com ${ }^{b}$
}

ARTICLE HISTORY

Received:

15 June 2017

Revised

14 July 2017

Accepted:

1 August 2017

Online available:

9 November 2017

Keywords (Calibri 10):

Brand Awareness,

Brand Association,

Percieved Quality,

Brand Loyalty

Kata Kunci:

Kesadaran Merek, Asosiasi Merek, Persepsi Kualitas, Loyalitas Merek

\section{ABSTRACT}

Introduction: This study aims to study the various elements of brand equity (brand equity) granulated sugar products, such as: brand awareness, brand association, brandperceived quality, and brand loyalty by comparing two brands of sugar products are Gulaku and Gupalas. Gulaku as first mover advantages which the first player to enter a particular industry is often considered to have the first opportunity to build market share since 2002, while Gupalas is a product that has just appeared in 2011.

Methods: The sampling method used is purposive sampling with the number of respondents who were taken as the sample in the study of 100 people consumers of sugar, especially housewives who are in the Madiun area. Analyzer used in this research is the analysis of the mean difference test through $t$ test and a confirmation through Manova test.

Results: Brand equity research results indicate that Gulaku have higher brand equity than Gupalas. The difference was due to the three elements of brand equity include brand awareness, brand associations and brand loyalty of Gulaku much higher than Gupalas. While Gupalas Gulaku only be offset in terms of perceived quality alone.

Conclusion and suggestion: This study is used as input Gupalas manufacturers namely PT. Nusantara Plantation XI as brand equity evaluation of Gupalas include brand equity, which is supposed to be improved. 


\begin{abstract}
ABSTRAK
Penelitian ini bertujuan untuk mempelajari berbagai unsur ekuitas merek (brand equity) produk gula pasir, seperti: kesadaran merek, asosiasi merek, kualitas persepsi merek, dan loyalitas merek dengan membandingkan dua merek produk gula yaitu Gulaku dan Gupalas. Keunggulan Gulaku sebagai first mover dimana pemain pertama yang memasuki industri tertentu seringkali dianggap memiliki peluang pertama untuk membangun pangsa pasar sejak 2002, sedangkan Gupalas merupakan produk yang baru muncul pada tahun 2011. Metode pengambilan sampel yang digunakan adalah purposive sampling dengan Jumlah responden yang diambil sebagai sampel dalam penelitian terhadap 100 orang konsumen gula khususnya ibu rumah tangga yang berada di wilayah Madiun. Alat analisis yang digunakan dalam penelitian ini adalah analisis uji beda rata-rata melalui uji t dan uji konfirmasi melalui uji Manova

Hasil penelitian ekuitas merek menunjukkan bahwa Gulaku memiliki ekuitas merek yang lebih tinggi daripada Gupalas. Perbedaan tersebut disebabkan oleh tiga unsur ekuitas merek yang meliputi kesadaran merek, asosiasi merek dan loyalitas merek Gulaku jauh lebih tinggi daripada Gupalas. Sedangkan Gupalas Gulaku hanya bisa diimbangi dari segi kualitas yang dirasa saja. Penelitian ini dijadikan sebagai input pabrikan Gupalas yaitu PT. Perkebunan Nusantara XI sebagai evaluasi ekuitas merek Gupalas termasuk ekuitas merek yang seharusnya ditingkatkan.
\end{abstract}

\title{
INTRODUCTION
}

Fenomena persaingan antar produsen untuk saling berebut konsumen membuat setiap produsen menyadari suatu kebutuhan untuk memaksimalkan aset-aset perusahaan demi kelangsungan hidup perusahaan. Merek menjadi faktor penting dalam persaingan dan menjadi aset perusahaan yang sangat bernilai untuk menghadapi persaingan. American Marketing Association (Kotler \& Keller, 2009) mendefinisikan merek sebagai nama, istilah, tanda, lambang, atau desain, atau kombinasinya, yang dimaksudkan untuk mengidentifikasikan barang atau jasa dari salah satu penjual atau kelompok penjual dan mendiferensiasikan mereka dari para pesaing. Ekuitas merek dapat tercermin dalam cara konsumen berpikir, merasa, dan bertindak dalam hubungannya dengan merek, dan juga harga, pangsa pasar,serta profitabilitas yang diberikan merek bagi perusahaan (Kotler \& Keller, 2009). Namun, yang paling umum digunakan adalah pendapat Aaker (1996), yaitu bahwa terdapat lima indikator atau dimensi utama pada ekuitas merek. Kelima indikator tersebut adalah kesadaran merek (brand awareness), asosiasi merek (brand associations), persepsi kualitas(perceived quality), loyalitas merek (brand loyalty) dan aset-aset lain yang berkaitan dengan merek (other brand-related assets). 
Dalam bisnis industri gula nasional, margin produsen gula dalam negeri yang tiap tahunnya menurun rata-rata $1,22 \%$ /tahun karena biaya produksi yang semakin tinggi (Badan Perencanaan Pembangunan Nasional, 2013), hal ini disebabkan biaya pengadaan yang mahal karena lokasi produksi gula yang terpencar-pencar. Untuk mengatasi permasalahan harga gula yang dihadapi produsen, maka terjadi transformasi gula pasir dari produk komoditas menjadi produk bermerek. Merek juga dapat menghasilkan pendapatan keuangan bagi perusahaan atau source of financial returns (Keller, 2008), untuk mengatasi semakin tipisnya marjin yang diperoleh produsen.

Pada tahun 2002, PT. Sugar Group Companies memulai untuk memasarkan gula pasir kemasan premium. Terobosan pertama kali pada industri gula di Indonesia dibuat Sugar Group Companies dengan mengeluarkan produk gula bermerek pertama di Indonesia, yaitu Gulaku. Menyusul pada tahun 2011, PT. Perkebunan Nusantara XI memproduksi gula pasir kemasan dengan merek Gupalas. Langkah tersebut ditempuh perusahaan untuk mengatasi permasalahan harga dan memberikan source of financial returns bagi perusahaan. Salah satu keunggulan produk Gupalas adalah bebas sulfur atau belerang. Sebuah teknologi baru yang diaplikasikan dalam proses pengolahan gula dengan sistem Karbonatasi yang menggantikan sistem lama yaitu sistem Sulfitasi yang masih menggunakan bahan pembantu proses berupa belerang. Hal ini tentunya dapat menjadi nilai positif Gupalas dimata konsumen terkait produknya yang menjanjikan kualitas lebih baik dibandingkan dengan produk lain. Seharusnya persepsi atas kualitas (percieved quality) akan terlihat baik bahkan mungkin lebih baik dari produk lain yang tidak menggunakan proses yang sama. Namun dalam perjalanannya, pemasaran produk Gupalas perlu dilakukan evaluasi kekuatan ekuitas merek terkait persaingannya dengan merek lain. Untuk mengevaluasi ekuitas merek Gupalas guna meningkatkan penjualannya maka dilakukan penelitian dengan membandingkan ekuitas merek Gupalas dan Gulaku. Gulaku dipilih sebagai pembanding karena merek tersebut merupakan leader market gula kemasan bermerek yang menguasai pasar sebesar $75 \%$ menurut Devisi Pemasaran PT. Perkebunan Nusantara XI (2014).

Berdasarkan latar belakang yang telah dipaparkan, maka PT. Perkebunan Nusantara XI selaku produsen Gupalas perlu melihat ekuitas merek tiap elemen untuk mengetahui elemen mana saja yang harus ditingkatkan dan elemen mana yang harus dipertahankan. Hal ini diperlukan untuk mengevaluasi elemen-elemen ekuitas merek untuk mengatasi permasalahan margin produsen yang tiap tahunnya menurun rata-rata 1,22\%/tahun dan total penjualan yang tidak stabil mulai tahun 2011 maka PT. Perkebunan Nusantara XI harus melakukan upaya pencapaian margin of return melalui nilai merek dari Gupalas. Teori yang paling umum digunakan adalah pendapat Aaker (1997), yaitu bahwa terdapat lima indikator atau dimensi utama pada ekuitas merek. Kelima indikator tersebut adalah kesadaran merek (brand awareness), asosiasi merek 
(brand associations), mutu yang dirasakan (perceivedquality), loyalitas merek (brand loyalty) dan aset-aset lain yang berkaitan dengan merek (other brand-related assets). Pada prakteknya, hanya empat dari kelima indikator tersebut yang digunakan pada penelitian-penelitian mengenai consumer-based brand equity, yaitu kesadaran merek, asosiasi merek, persepsi kualitas, dan loyalitas merek. Hal ini dikarenakan aset-aset lain yang berkaitan dengan merek (seperti hak paten dan saluran distribusi), tidak berhubungan secara langsung dengan konsumen.

Evaluasi ekuitas merek Gupalas dapat dilakukan dengan membandingkan ekuitas merek Gupalas dengan Gulaku yang merupakan market leader gula bermerek. Penelitian ini dilakukan di wilayah Madiun karena wilayah Madiun didominasi wilayah perdesaan yang tingkat konsumsi gulanya naik dari tahun ke tahun. Madiun juga merupakan wilayah pabrik milik PT. Perkebunan Nusantara XI yang merupakan tuan rumah dari produk Gupalas. Madiun adalah wilayah yang tepat dalam mengevaluasi produk PT. Perkebunan Nusantara XI karena seharusnya Gupalas memiliki ekuitas merek yang baik di wilayahnya sendiri, untuk selanjutnya menjadi tolok ukur dalam mengembangkan ekuitas merek di wilayah lainnya.

\section{LITERATURE REVIEW}

\section{The traditional society}

Ekuitas merek menurut Kotler dan Amstrong (2008) adalah nilai dari suatu merek, yang meliputi elemen ekuitas merek yang tinggi serta aset lain (paten, merek dagang, dan hubungan saluran). Keller (2003) mendefinisikan ekuitas merek sebagai nilai yang secara langsung ataupun tidak langsung dimiliki oleh merek. Dengan demikian dapat dinyatakan bahwa ekuitas merekadalah kekuatan merek yang menjanjikan nilai yang diharapkan konsumen atas suatu produk sehingga akhirnya konsumen akan merasa mendapatkan kepuasan yang lebih bila dibanding produk-produk lainnya (McDonald, 2004).

Teori yang paling umum digunakan adalah pendapat Aaker (1997), yaitu bahwa terdapat lima indikator atau dimensi utama pada ekuitas merek. Kelima indikator tersebut adalah kesadaran merek (brand awareness), asosiasi merek (brand associations), mutu yang dirasakan (perceivedquality), loyalitas merek (brand loyalty) dan aset-aset lain yang berkaitan dengan merek (other brand-related assets). Pada prakteknya, hanya empat dari kelima indikator tersebut yang digunakan pada penelitianpenelitian mengenai consumer-based brandequity, yaitu kesadaran merek, asosiasi merek, persepsi kualitas, dan loyalitas merek. Hal ini dikarenakan aset-aset lain yang berkaitan dengan merek (seperti hak paten dan saluran distribusi), tidak berhubungan secara langsung dengan konsumen. 


\section{Hypothesis}

Sejak tahun 2011, PT. Perkebunan Nusantara XI memproduksi gula pasir kemasan dengan merek Gupalas. Langkah tersebut ditempuh perusahaan untuk mengatasi permasalahan margin produsen yang tiap tahunnya menurun rata-rata $1,22 \%$ tiap tahun sehingga merek mampu memberikan source of financial returns bagi perusahaan. Dalam upaya evaluasi merek Gupalas yang telah beredar selama ini, maka diperlukan analisis ekuitas merek Gupalas dibandingkan Gulaku yang merupakan market leader gula bermerek sebagai upaya perbaikan ekuitas merek dari Gupalas. Elemen ekuitas merek mana saja yang harus diperkuat Gupalas guna mengatasi persaingan merek gula pasir yang semakin ketat belakangan ini. Maka hipotesis yang dirumuskan dari penelitian ini adalah sebagai berikut:

1. $\mathrm{H} 1=$ Kesadaran merek gula pasir merek Gulaku lebih tinggi dibandingkan dengan Gupalas

Produk Gulaku memiliki kesadaran merek lebih tinggi karena muncul pertama kali sebagai produk gula pasir bermerek yang pertama kali, yaitu sejak tahun 2002 . Tranformasi gula pasir dari produk komoditas menjadi produk bermerek dimulai oleh PT. Sugar Group Companies melalui gula pasir merek Gulaku mampu memikat hati konsumen sehingga tercipta segmen pasar tersendiri.Menurut Aaker (1997) "Kesadaran Merek adalah kesanggupan seorang pembeli untuk mengenali dan mengingat kembali bahwa suatu merek merupakan perwujudan kategori produk tertentu". Kesadaran merek membutuhkan jangkauan kontinum (Continum Ranging) dari perasaan yang tak pasti bahwa merek tertentu dikenal menjadi keyakinan bahwa produk tersebut merupakan satu-satunya dalam kelas produk bersangkutan. Gulaku cukup lama menjadi satu-satunya produk gula pasir tanpa pesaing dan dalam waktu belakangan ini mulai muncul beberapa pesaingnya.

2. $\mathrm{H}_{2}$ = Asosiasi merek gula pasir merek Gulaku lebih tinggi dibandingkan dengan Gupalas

Menurut Aaker (1997) adalah segala hal yang berkaitan dengan ingatan mengenai suatu merek. Kesan-kesan yang terkait pada merek akan semakin meningkat dengan semakin banyaknya penampakan merek tersebut dalam strategi komunikasi. Terkait promosi yang dilakukan oleh Gulaku yang masif dalam skala nasional tentu saja kesan-kesan yang terkait pada merek juga sangat kuat di benak konsumen. Sehingga dapat disimpulkan bahwa asosiasi merek Gulaku diduga lebih tinggi dibandingkan dengan Gupalas.

3. $\mathrm{H} 3=$ Persepsi kualitas gula pasir merek Gupalas lebih tinggi dibandingkan dengan Gulaku 
Salah satu keunggulan produk Gupalas adalah bebas sulfur atau belerang. Sebuah teknologi baru yang diaplikasikan dalam proses pengolahan gula dengan sistem Karbonatasi yang menggantikan sistem lama yaitu sistem Sulfitasi yang masih menggunakan bahan pembantu proses berupa belerang. Sistem Sulfitasi, yaitu sistem klarifikasi yang menggunakan hidrolisa kapur dan Sulfur (gas) sebagai bahan pemurniannya, rata rata kualitas warna yang dihasilkan 150-300 IU,sedangkan sistem Karbonatasi atau sistem klarifikasi yang menggunakan hidrolisa kapur dan gas CO2 sebagai bahan pemurniannya, sistem ini menghasilkan kualitas gula putih (lebih baik dari dua sistem sebelumnya) dengan kadar warna100 IU ( B. Wibowo, 2012). Hal ini merupakan sebuah nilai positif Gupalas dimata konsumen terkait produknya yang menjanjikan kualitas lebih baik dibandingkan dengan produk lain.

Menurut Aaker (1997) "Kesan atau persepsi kualitas merupakan persepsi konsumen terhadap keseluruhan kualitas atau keunggulan suatu produk atau jasa layanan yang sama dengan maksud yang diharapkannya".Persepsi kualitas adalah salah satu kunci dimensi ekuitas merek.Jaminan kualitas aktual atau obyektif Gupalas memberikan jaminan produk yang lebih baik, sehingga dirumuskan bahwa kualitas gula pasir merek Gupalas diduga lebih tinggi dibandingkan dengan Gulaku.

4. H4 = Loyalitas merek gula pasir merek Gulaku lebih tinggi dibandingkan dengan Gupalas

Loyalitas merek merupakan ukuran ketertarikan pelanggan terhadap sebuah merek (Aaker, 1997). Loyalitas merek terhadap suatu produk dapat menjadi sebuah ukuran bagi perusahaan dalam menentukan banyaknya perolehan laba dan memprediksi seberapa banyak konsumen yang mungkin bisa berpindah ke merek kompetitor yang lain.Loyalitas konsumen terhadap suatu merek dapat menjadi penghalang kompetitor lain untuk masuk dalam pasar, pemberian harga premium terhadap produk dan sebagai pertahanan yang kuat terhadap persaingan harga (Aaker, 1997).Terkait dengan usia, faktor promosi dan pertumbuhan penjualan dari tahun ke tahun tentu saja Gulaku memiliki loyalitas yang tinggi.

Dari rumusan tersebut diatas, secara umum Gulaku diduga memiliki ekuitas merek yang lebih tinggi dibandingkan dengan Gupalas dikarenakan faktor usia Gulaku yang lebih lama dan promosinya dalam skala nasional yang lebih gencar. Namun jika dilihat dari salah satu elemen penyusun ekuitas merek yaitu persepsi kualitas, Gupalas memiliki keunggulan kualitas produk bebas sulfur atau belerang karena proses pengolahannya menggunakan sistem Karbonatasi.Akan tetapi, hal tersebut masih perlu diuji terutama untuk wilayah Madiun yang yang merupakan kawasan persebaran Pabrik Gula milik PT. Perkebunan Nusantara XI. 
5. H5= Ekuitas merek gula pasir merek Gulaku lebih tinggi dibandingkan dengan Gupalas

Hal tersebut disebabkan karena tiga elemen ekuitas merek meliputi kesadaran merek, asosiasi merek dan loyalitas merek Gulaku lebih tinggi dibandingkan Gupalas. Sedangkan Gupalas memiliki keunggulan dalam hal kualitas dengan sistem pengolahan karbonatasi bebas sulfur atau belerang dalam hal persepsi kualitas saja.

\section{RESEARCH METHODS}

Dalam penelitian ini digunakan pendekatan secara kuantitatif. Penelitian ini bertujuan untuk mengungkap fakta tentang ekuitas merek yang terdiri dari empat elemen dari produk Gulaku dan Gupalas di wilayah Madiun. Populasi dari penelitian ini adalah ibu-ibu rumah tangga pembeli gula pasir di wilayah Madiun. Kuesioner disebar kepada responden mulai tanggal $1 \mathrm{~s} / \mathrm{d} 15$ Desember 2014. Segmen produk gula kemasan premium adalah keluarga dengan penghasilan menengah dan menengah keatas. Teknik pengambilan sampel dalam penelitian ini adalah nonprobability sampling (penarikan sampel secara tidak acak). Bagian dari nonprobability sampling yang digunakan adalah purposive sampling. Alat analisis yang digunakan dalam penelitian ini adalah analisa uji beda mean melalui uji t dan sebagai konfirmasi melalui uji Manova dengan software SPSS for windows ver. 20.

Dalam penelitian ini, yang dinilai tepat dan representatif sebagai sumber informasi yaitu ibu rumah tangga dengan kriteria sebagai berikut:

1. Dari keluarga kelas menengah (penghasilan $2,6 \mathrm{~s} / \mathrm{d} 6$ juta) dan keluarga menengah ke atas ( penghasilan $>6$ juta)

2. Telah mengenal produk gula pasir kemasan dengan merek Gulaku dan Gupalas

3. Jumlah Sampel $=5 \times 20 \mathrm{bh}=100$ orang responden

Variabel yang digunakan dalam penelitian ini adalah ekuitas merek dengan sub variabel yang digunakan adalah sebagai berikut : Kesadaran merek (KM) ; Asosiasi Merek (AM); Persepsi Kualitas Merek (PK): Loyalitas Merek (LM). Variabel ekuitas merek pada penelitian ini didefinisikan sebagai nilai dari produk gula pasir merek Gulaku dan Gupalas yang diukur dari kekuatan kesadaran merek, asosiasi merek, persepsi kualitas dan loyalitas merek. Sedangkan Sub variabel dalam penelitian ini, didefinisikan sebagai berikut :

Tabel 1

Indikator Instrumen Pengukuran Ekuitas Merek

\begin{tabular}{lllll}
\hline Variabel & Dimensi & \multicolumn{1}{c}{ Indikator Instrumen } & Sumber \\
\hline KM & $\begin{array}{l}\text { Brand } \\
\text { Knowledge }\end{array}$ & Saya telah mengenal merek gula pasir (Gulaku/Gupalas) & Fayrene \& Chai \\
& Brand & Saya dengan mudah mengenali gula pasir merek & \\
\cline { 2 - 5 } & recognition & (Gulaku/Gupalas) ketika melihat kemasannya (LM 2) & \\
\hline AM & Corporate & Gula pasir merek (Gulaku/Gupalas) adalah produk yang & Fayrene dan Chai \\
\hline
\end{tabular}




\begin{tabular}{|c|c|c|c|}
\hline & ability & berasal dari perusahaan yang memiliki reputasi baik (AM 1) & Lee, 2011 \\
\hline & $\begin{array}{l}\text { Functional } \\
\text { Product } \\
\text { Atribute }\end{array}$ & $\begin{array}{l}\text { Gula pasir merek (Gulaku/Gupalas) adalah produk yang bebas } \\
\text { dari produk bahan kimia yang berbahaya (AM 2) }\end{array}$ & \\
\hline \multirow[t]{5}{*}{ PK } & $\begin{array}{l}\text { Good } \\
\text { quality }\end{array}$ & $\begin{array}{l}\text { Menurut pendapat saya, gula pasir merek (Gulaku/Gupalas) } \\
\text { merupakan produk yang memiliki kualitas baik (PK 1) }\end{array}$ & \multirow{5}{*}{$\begin{array}{ll}\text { Pappu, } & \text { Quester } \\
\text { dan } & \text { Cooksey, } \\
2005 & \end{array}$} \\
\hline & $\begin{array}{l}\text { Consistent } \\
\text { quality }\end{array}$ & $\begin{array}{l}\text { Menurut pendapat saya, gula pasir merek (Gulaku/Gupalas) } \\
\text { merupakan produk yang kualitasnya terjaga dengan } \\
\text { konsisten (PK 2) }\end{array}$ & \\
\hline & $\begin{array}{l}\text { Very } \\
\text { durable }\end{array}$ & $\begin{array}{l}\text { Menurut pendapat saya, gula pasir merek (Gulaku/Gupalas) } \\
\text { merupakan produk yang tahan lama atau awet disimpan } \\
\text { (PK3) }\end{array}$ & \\
\hline & $\begin{array}{l}\text { Very } \\
\text { reliable }\end{array}$ & $\begin{array}{l}\text { Menurut pendapat saya, Gula pasir merek (Gulaku/Gupalas) } \\
\text { merupakan produk yang dapat diandalkan sebagai pemanis } \\
\text { makanan atau minuman (PK 4) }\end{array}$ & \\
\hline & $\begin{array}{l}\text { Excellent } \\
\text { Features }\end{array}$ & $\begin{array}{l}\text { Menurut pendapat saya, Gula pasir merek (Gulaku/Gupalas) } \\
\text { merupakan produk dengan kemasan yang sempurna (PK 5) }\end{array}$ & \\
\hline \multirow{3}{*}{$\begin{array}{l}\text { Loyalitas } \\
\text { Merek } \\
\text { (LM) }\end{array}$} & First Choice & $\begin{array}{l}\text { Gula pasir merek (Gulaku/Gupalas) adalah pilihan utama } \\
\text { ketika saya ingin membeli gula.( LM 1) }\end{array}$ & \multirow{3}{*}{$\begin{array}{l}\text { - Pappu, Quester } \\
\text { dan Cooksey, } \\
2005\end{array}$} \\
\hline & $\begin{array}{l}\text { Price } \\
\text { Premium }\end{array}$ & $\begin{array}{l}\text { Saya tidak akan membeli gula pasir merek lain jika merek } \\
\text { (Gulaku/Gupalas) tidak ada di tempat belanja. ( LM 2) }\end{array}$ & \\
\hline & $\begin{array}{l}\text { Price } \\
\text { premium }\end{array}$ & $\begin{array}{l}\text { Saya merasa rugi jika saya mengkonsumsi gula pasir merek } \\
\text { lain selain gula pasir merek (Gulaku/Gupalas) (LM 3) }\end{array}$ & \\
\hline
\end{tabular}

\section{RESULT AND ANALYSIS}

Penelitian ini dilaksanakan dengan membagi kuesioner kepada 100 responden di wilayah kabupaten Madiun. Berikut karakteristik demografi subjek penelitian yang tersaji dalam tabel berikut :

Tabel 2

Data responden berdasarkan usia

\begin{tabular}{cc}
\hline Usia (thn) & Jumlah \\
\hline $20-30$ & 33 \\
$31-40$ & 41 \\
$41-50$ & 26 \\
JUMLAH & 100 \\
\hline
\end{tabular}

Sumber: Data Diolah

Tabel 3

Data responden berdasarkan pekerjaan

\begin{tabular}{lc}
\hline \multicolumn{1}{c}{ Pekerjaan } & Jumlah \\
\hline PNS/TNI/POLRI & 22 \\
KARYAWAN SWATA & 33
\end{tabular}

Published by University of Airlangga.

This is an open access article under the CC BY SA license (https://creativecommons.org/licenses/by-sa/4.0/) 


\begin{tabular}{lc}
$\begin{array}{l}\text { WIRASWASTA } \\
\text { IBU RUMAH TANGGA } \\
\text { JUMLAH }\end{array}$ & 14 \\
Sumber: Data Diolah & 31 \\
Tabel 4 & 100 \\
Data responden berdasarkan Ekonomi Keluarga \\
\hline Ekonomi Keluarga & Jumlah \\
\hline MENENGAH & 77 \\
MENENGAH KE ATAS & 23 \\
JUMLAH & 100
\end{tabular}

Sumber: Data Diolah

Tabel 5

Kesimpulan Hasil Uji Hipotesis Penelitian

\begin{tabular}{|c|c|c|c|c|}
\hline & Rumusan Hipotesis & Sig. Uji t & Sig. Uji & Keterangan \\
\hline $\mathrm{H} 1$ & $\begin{array}{l}\text { Kesadaran merek gula pasir merek } \\
\text { Gulaku lebih tinggi dibandingkan dengan } \\
\text { Gupalas }\end{array}$ & 0,000 & 0,000 & $\begin{array}{lrrr}\text { Probabilitas } & \text { hasil } & \text { uji t } & \text { dan } \\
\text { Manova }< & 0,05 & \text { maka } & \mathrm{H} 1 \\
\text { diterima } & & & \end{array}$ \\
\hline $\mathrm{H} 2$ & $\begin{array}{l}\text { Asosiasi merek gula pasir merek Gulaku } \\
\text { lebih tinggi dibandingkan dengan } \\
\text { Gupalas }\end{array}$ & 0,001 & 0,000 & $\begin{array}{l}\text { Probabilitas hasil uji t dan } \\
\text { Manova }<0,05 \text { maka } \mathrm{H} 2 \\
\text { diterima }\end{array}$ \\
\hline H3 & $\begin{array}{lrl}\text { Persepsi kualitas gula } & \text { pasir merek } \\
\text { Gupalas lebih tinggi } & \text { dibandingkan } \\
\text { dengan Gulaku } & & \end{array}$ & 0,115 & 0,074 & $\begin{array}{l}\text { Probabilitas hasil uji } t \text { dan } \\
\text { Manova }>0,05 \text { maka H3 ditolak }\end{array}$ \\
\hline $\mathrm{H} 4$ & $\begin{array}{l}\text { Loyalitas merek gula pasir merek Gulaku } \\
\text { lebih tinggi dibandingkan dengan } \\
\text { Gupalas }\end{array}$ & 0,000 & 0,000 & $\begin{array}{l}\text { Probabilitas hasil uji t dan } \\
\text { Manova }<0,05 \text { maka H4 } \\
\text { diterima }\end{array}$ \\
\hline H5 & $\begin{array}{l}\text { Ekuitas merek gula pasir merek Gulaku } \\
\text { lebih tinggi dibandingkan dengan } \\
\text { Gupalas }\end{array}$ & 0,000 & 0,000 & $\begin{array}{l}\text { Probabilitas hasil uji t dan } \\
\text { Manova }<0,05 \text { maka H5 } \\
\text { diterima }\end{array}$ \\
\hline
\end{tabular}

Sumber: Data Diolah (SPSS)

\section{Pembahasan Penelitian Perbandingan Kesadaran Merek Gulaku dan Gupalas}

Dari hasil analisis data dengan uji t, variabel kesadaran merek antara Gulaku dan Gupalas mempunyai probabilitas 0,000 sehingga Hipotesis bahwa Kesadaran merek gula pasir merek Gulaku lebih tinggi dibandingkan dengan Gupalas dapat diterima. Hipotesis ini juga dikuatkan dengan uji Manova yang menunjukkan bahwa nilai probabilitas perbedaan antara Gulaku dan Gupalas adalah 0,000 ( kurang dari 0,05 ). Dari hasil uji t rata-rata kesadaran merek Gulaku adalah sebesar 3,5450 dan Gupalas sebesar 3,0950, dengan selisih rata-ratanya sebesar 0,3825 
Menurut Aaker (1997), Kesadaran Merek adalah kesanggupan seorang pembeli untuk mengenali dan mengingat kembali bahwa suatu merek merupakan perwujudan kategori produk tertentu. Jawaban responden pada indikator variabel kesadaran merek Gulaku memiliki modus jawaban pada opsi S ( Setuju, bobot $=4$ ) sebesar $47 \%$, hal ini berarti responden merasa cukup baik mengenal merek Gulaku. Sedangkan Jawaban responden pada indikator variabel kesadaran merek Gupalas memiliki modus jawaban pada opsi CS ( Cukup Setuju, bobot = 3) sebesar 45\% dan opsi TS ( Tidak Setuju, bobot = 2 ) cukup banyak yaitu sebesar $23 \%$ hal ini berarti responden kurang mengenal merek Gupalas. Hal ini dikarenakan faktor usia Gulaku yang lebih dahulu muncul sebagai produk gula pasir kemasan dan kegiatan promosi yang gencar dan masif yang telah dilakukan Sugar Group Companies dalam beberapa tahun terakhir dalam skala nasional melalui media televisi.

\section{Pembahasan Hasil Penelitian Perbandingan Asosiasi Merek Gulaku dan Gupalas}

Dari hasil analisis data dengan uji t, variabel kesadaran merek antara Gulaku dan Gupalas mempunyai probabilitas 0,001 sehingga hipotesis bahwa asosiasi merek gula pasir merek Gulaku lebih tinggi dibandingkan dengan Gupalas dapat diterima. Hipotesis ini juga dikuatkan dengan uji Manova yang menunjukkan bahwa nilai probabilitas perbedaan asosiasi merek antara Gulaku dan Gupalas adalah 0,000 ( kurang dari 0,05 ). Dari hasil uji t rata-rata asosiasi merek Gulaku adalah sebesar 3,3650 dan Gupalas sebesar 3,0050, dengan selisih rata-ratanya sebesar 0,3600.

Pengertian asosiasi merek menurut Aaker (1997) adalah segala hal yang berkaitan dengan ingatan mengenai suatu merek. Kesan-kesan yang terkait pada merek akan semakin meningkat dengan semakin banyaknya penampakan merek tersebut dalam strategi komunikasi. Fungsi brand association menjadi pijakan bagi konsumen dalam memutuskan pembelian suatu produk. Jawaban responden pada indikator variabel asosiasi merek Gulaku memiliki modus jawaban pada opsi S ( Setuju, bobot $=4$ ) sebesar $43 \%$, hal ini berarti responden memiliki asosiasi merek yang sangat baik terhadap Gulaku. Sedangkan Jawaban responden pada indikator variabel asosiasi merek Gupalas memiliki modus jawaban pada opsi 3 ( Cukup Setuju, bobot $=3$ ) sebesar $47 \%$, hal ini berarti responden sebenarnya memiliki asosiasi merek yang cukup baik terhadap Gupalas.

Dari penjabaran hasil analisis diatas, terdapat perbedaan asosiasi merek yang sangat signifikan antara Gulaku dan Gupalas. Hal ini disebabkan karena strategi promosi yang diimbangi dengan konsistensi mutu Gulaku dan reputasi Sugar Group Companies yang dipandang baik oleh responden. Sedangkan tanggapan responden mengenai asosiasi merek Gupalas cukup baik dikarenakan wilayah madiun merupakan daerah persebaran pabrik gula milik PT. Perkebunan Nusantara XI, namun dari segi pendekatan 
komunikasi dengan konsumen dalam hal memberi keyakinan bahwa Gupalas adalah produk dengan kesan baik, Gupalas masih kalah dengan Gulaku.

\section{Pembahasan Hasil Penelitian Perbandingan Persepsi Kualitas Gulaku dan Gupalas}

Dari hasil analisis data dengan uji t, variabel persepsi kualitas antara Gulaku dan Gupalas mempunyai probabilitas 0,115 sehingga Hipotesis bahwa persepsi kualitas gula pasir merek Gupalas lebih tinggi dibandingkan dengan Gulakutidak dapat diterima. Hipotesis ini juga dikuatkan dengan uji Manova yang menunjukkan bahwa nilai probabilitas perbedaan antara Gulaku dan Gupalas adalah 0,074 ( lebih dari 0,05 ). Dari hasil uji t rata-rata persepsi kualitas Gulaku adalah sebesar 3,3220 dan Gupalas sebesar 3,1880, dengan selisih rata-ratanya sebesar 0,134.

Menurut Aaker (1997) "Kesan atau persepsi kualitas merupakan persepsi konsumen terhadap keseluruhan kualitas atau keunggulan suatu produk atau jasa layanan yang sama dengan maksud yang diharapkannya". Jawaban responden pada indikator variabel persepsi kualitas Gulaku dan Gupalas memiliki modus jawaban pada opsi CS ( Cukup Setuju, bobot = 3 ) dengan prosentase yang cukup berimbang, hal ini berarti responden memiliki persepsi kualitas yang cukup baik terhadap Gulaku dan Gupalas. Secara visual baik kemasan maupun tampilan kualitas produk Gulaku dan Gupalas cukup berimbang. Hal ini berarti responden menganggap bahwa merek Gulaku dan Gupalas memiliki persepsi keseluruhan kualitas yang sesuai harapan konsumen akan kedua produk tersebut.

\section{Pembahasan Hasil Penelitian Perbandingan Loyalitas Merek Gulaku dan Gupalas}

Dari hasil analisis data dengan uji t, variabel loyalitas merek antara Gulaku dan Gupalas mempunyai probabilitas 0,000 sehingga hipotesis bahwa loyalitas merek gula pasir merek Gulaku lebih tinggi dibandingkan dengan Gupalas dapat diterima. Hipotesis ini juga dikuatkan dengan uji Manova yang menunjukkan bahwa nilai probabilitas perbedaan asosiasi merek antara Gulaku dan Gupalas adalah 0,000 ( kurang dari 0,05 ). Dari hasil uji t rata-rata loyalitas merek Gulaku adalah sebesar 3,0095 dan Gupalas sebesar 2,4191, dengan selisih rata-ratanya sebesar 0,5904.

Loyalitas merek merupakan ukuran ketertarikan pelanggan terhadap sebuah merek (Aaker, 1997). Loyalitas merek terhadap suatu produk dapat menjadi sebuah ukuran bagi perusahaan dalam menentukan banyaknya perolehan laba dan memprediksi seberapa banyak konsumen yang mungkin bisa berpindah ke merek kompetitor yang lain. Menurut Mowen (1995), loyalitas merek didefinisikan sebagai tingkatan dimana pelanggan memiliki sikap positif terhadap suatu merek, memiliki komitmen dan cenderung untuk terus melanjutkan membeli produk dengan suatu merek tertentu dimasa yang akan datang. Dengan demikian, loyalitasmerek secara langsung dipengaruhi oleh kepuasan atau ketidakpuasan pelanggan terhadap merek tertentu.Jawaban 
responden pada indikator variabel loyalitas merek Gulaku memiliki modus jawaban pada opsi S (Setuju, bobot = 3 ) sebesar 38\% dan Gupalas memiliki modus jawaban pada opsi TS ( Tidak Setuju, bobot $=2$ ) sebesar 58\%, hal ini berarti responden memiliki loyalitas merek yang cukup baik terhadap Gulaku dan kurang baik terhadap Gupalas. Dengan demikian merek Gupalas kurang mendapatkan kesetiaan konsumennya.

\section{Pembahasan Hasil Penelitian Perbandingan Ekuitas Merek Gulaku dan Gupalas}

Dari hasil analisis data dengan uji t, ekuitas merek antara Gulaku dan Gupalas mempunyai probabilitas 0,000 sehingga hipotesis bahwa ekuitas merek gula pasir merek Gulaku lebih tinggi dibandingkan dengan Gupalas dapat diterima. Dari hasil uji t rata-rata ekuitas merek Gulaku sebesar 3,3109 dan Gupalas sebesar 2,9281 dengan selisih ratarata 0,3828. Dari hasil uji Manovapengujian didasarkan pada Pillai's Trace, Wilks' Lambda, Hotelling's Trace, Roy's Largest Root menunjukkan angka 0,000 yang berarti nilai probabilitasnya kurang dari 0,005 maka variabel kesadaran merek, asosiasi merek, persepsi kualitas dan loyalitas merek menunjukkan perbedaan secara general pada merek Gulaku dan Gupalas, hal ini dapat diartikan bahwa ekuitas merek Gulaku dan Gupalas memilki perbedaan. Hasil penelitian ini didukung oleh hasil penelitian sebelumnya yang dilakukan oleh Gupta \& Verma (2008) yang menunjukkan hasil bahwa ekuitas merek dari dua produk telepon berbeda secara signifikan, tetapi tidak searah dengan hasil penelitian yang Makerti ( 2010).

\section{CONCLUSION}

Berdasarkan hasil pembahasan yang telah diuraikan sebelumnya, maka dapat diambil beberapa simpulan sebagai berikut :

1. Terdapat perbedaan kesadaran merek yang signifikan antara gula pasir merek Gulaku dengan Gupalas. Gulaku memiliki kesadaran merek yang lebih tinggi karena faktor usia dan strategi promosi yang telah dilakukan selama ini jauh lebih lama dan intensif di beberapa media.

2. Terdapat perbedaan asosiasi merek yang signifikan antara gula pasir merek Gulaku dengan Gupalas. Hal ini disebabkan karena Gulaku merupakan produk sehat bebas dari bahan kimia berbahaya dan reputasi Sugar Group Companies yang dipandang baik oleh konsumen. Sedangkan tanggapan responden mengenai asosiasi merek Gupalas cukup baik dikarenakan wilayah madiun merupakan daerah persebaran pabrik gula milik PT. Perkebunan Nusantara $\mathrm{XI}$, namun dari segi pendekatan komunikasi dengan konsumen dalam hal memberi keyakinan bahwa Gupalas adalah produk dengan kesan baik, Gupalas masih kalah dengan Gulaku.

3. Tidak terdapat perbedaan persepsi kualitas yang signifikan antara gula pasir merek Gulaku dengan Gupalas. Secara visual baik kemasan maupun tampilan kualitas produk Gulaku dan Gupalas cukup berimbang. Hal ini berarti responden menganggap bahwa merek Gulaku dan 
Gupalas memiliki persepsi keseluruhan kualitas yang baik sesuai harapan konsumen akan produk tersebut. Persepsi konsumen menganggap gula pasir kemasan bermerek secara keseluruhan kualitas lebih unggul dibanding gula pasir yang dikemasi tanpa merek. Gupalas dengan sistem pengolahan karbonatasi secara kualitas produk pada dasarnya mampu bersaing imbang dengan Gulaku.

4. Terdapat perbedaan loyalitas merek yang signifikan antara gula pasir merek Gulaku dengan Gupalas. Gulaku memiliki loyalitas merek yang lebih baik dibandingkan Gupalas. Dengan demikian merek Gupalas kurang mendapatkan kesetiaan konsumennya sehingga konsumen dengan mudah membeli produk lain ketika diberikan alternatif pilihan gula pasir. Sedangkan terhadap Gulaku, konsumen memiliki sikap positif, memiliki komitmen dan cenderung untuk terus membelinya.

5. Terdapat perbedaan ekuitas merek yang signifikan antara gula pasir merek Gulaku dengan Gupalas. Perbedaan tersebut disebabkan karena tiga elemen ekuitas merek meliputi kesadaran merek, asosiasi merek dan loyalitas merek Gulaku jauh lebih tinggi dibandingkan Gupalas. Sedangkan Gupalas hanya bisa mengimbangi Gulaku dalam hal persepsi kualitas saja.

\section{Saran}

Untuk produsen Gupalas yaitu PT. Perkebunan Nusantara XI, bahwa di Madiun merupakan daerah produksi gula milik PT. Perkebunan Nusantara XI yang meliputi 5 ( lima) Pabrik Gula yang posisinya tersebar di wilayah tersebut. Namun, pada kenyataannya Gupalas belum bisa mengungguli Gulaku dalam hal kesadaran merek, asosiasi merek dan loyalitas merek di wilayah Madiun apalagi wilayah lainnya. Maka dari itu disarankan kepada PT. Perkebunan Nusantara XI selaku produsen Gupalas:

a. Meningkatkan Kesadaran Merek

Untuk menimbulkan kesadaran merek pada konsumen dibutuhkan suatu stimulus atau hal-hal yang dapat merangsang munculnya kesadaran merek tersebut. Salah satu cara untuk mendapatkan kesadaran merek konsumen yaitu dengan melakukan kegiatan promosi. Dengan kesadaran merek yang tinggi,memungkinkan perusahaan untuk meningkatkan penjualan atas produkmereka.

b. Meningkatkan Asosiasi Merek

Asosiasi merek sangat berkaitan erat dengan brand image. Faktor - faktor pendukung terbentuknya brand image dalam keterkaitannya dengan asosiasi merek (Keller, 2003)

- Favorability of brand association (Keunggulan asosiasi merek)

Salah satu faktor pembentuk brand image adalah keunggulan produk, dimana produk tersebut unggul dalam persaingan, sertifikasi SNI, label halal MUI dan produknya yang bebas belerang seharusnya lebih ditonjolkan dalam kegiatan promosi. Ciri khas produk dengan kualitas yang dinyatakan lebih sehat karena 
bebas belerang seharusnya lebih diangkat dimata konsumen untuk meningkatkan asosiasi merek yang positif terhadap Gupalas.

- Strength of brand association/familiarity of brand association (Kekuatan asosiasi merek)

PT. Perkebunan Nusantara XI harus membangun kepopuleran merek dengan strategi komunikasi melalui periklanan.Strategi yang digunakan adalah dengan melakukan kampanye iklan dengan slogan yang positif dan kuat menancap di benak konsumen, misalnya dengan slogan "Gupalas : Gula Pasir dengan Kualitas Tak Tertandingi". Setiap merek yang berharga mempunyai jiwa, suatu kepribadian khusus.Adalah kewajiban mendasar bagi PT. Perkebunan Nusantara XI untuk dapat mengungkapkan, mensosialisasikan jiwa/ kepribadian Gupalas dalam satu bentuk iklan, ataupun bentuk kegiatan promosi dan pemasaran lainnya.

- Uniquesness of brand association (Keunikan asosiasi merek) Merupakan keunikan-keunikan yang dimiliki oleh produk tersebut. PT. Perkebunan Nusantara XI adalah perusahaan yang pada mulanya adalah perusahaan rintisan Belanda, yang rata-rata pabriknya berdiri tahun 1900. Oleh karena itu, dalam hal memproduksi gula, PT. Perkebunan Nusantara adalah ahlinya bahkan expert di bidangnya.Hal ini seharusnya dikomunikasikan kepada konsumen sehingga keunikan produsen Gupalas yaitu PT. Perkebunan Nusantara XI dimengerti oleh konsumen.

c. Meningkatkan Loyalitas Merek

- Beberapa hal yang harus dilakukan PT. Perkebunan Nusantara XI untuk meningkatkan loyalitas merek gulaku adalah :

- Kelebihan Gupalas bahwa produknya lebih berkualitas, dengan mengusung produknya yang lebih sehat bebas belerang dibandingproduk pesaing haruslah dipertahankan.

- PT. Perkebunan Nusantara harus melakukan inovasi berkelanjutan terhadap merek Gupalas. Inovasi atribut-atribut produk mengikuti perubahan yang diinginkan konsumen. Oleh karena itu, produsen harus jeli dalam membaca perubahan konsumen.

- Konsumen seharusnya diberikan pilihan-pilihan terhadap merek Gupalas dengan menciptakan varian-varianbaru baik dari berat kemasan maupun model kemasan bahkan jenis varian produk. Banyak merek-merek besar yang berhasil mempertahankan pelanggan dikarenakan mereka membuat varian-varian baru.

- Program promosi Gupalas yang berkelanjutan merupakan hal wajib bagi PT. Perkebunan Nusantara XI, Penerapan program promosi sangat diperlukan sebagai salah satu upaya mempertahankan konsumen. Promosi diskon, paket produk, 
paket bundling serta paket dengan harga khusus menjadi salah satu strategi yang terbukti ampuh membangun loyalitas konsumen.

d. Persepsi Kualitas

Persepsi kualitas konsumen terhadap Gupalas sudah baik.Hal ini merupakam indikasi bahwa konsumen sudah dapat melihat keunggulan Gupalas dalam hal kualitas produk yang bebas belerang... Investasi peralatan terkait peningkatan kualitas seharusnya dapat diminimalkan, sehingga tidak terjadi pemborosan biaya perusahaan.

Apabila kualitas nyata produk tetap dipertahankan dan perusahaan berusaha untuk mengkomunikasikan keunggulan produknya dalam kegiatan promosi maka kesadaran maupun asosiasi merek Gupalas dapat terbentuk dengan baik sehingga loyalitas konsumen juga akan meningkat.

Sedangkan Gulaku sebagai first mover advantages yaitu pemain pertama yang masuk ke industri tertentu sering dianggap memiliki peluang pertama untuk membangun pangsa pasar.Produsen Gulaku dengan posisi yang cukup menguntungkan karena merupakan produk gula pasir pertama yang beredar di pasar sejak tahun 2002 dan waktu promosi yang cukup lama dibandingkan produk lain diharapkan selalu waspada terhadap beberapa kompetitor lain. Keunggulan ekuitas merek Gulaku harus tetap dipertahankan bahkan dapat ditingkatkan dengan strategi promosi untuk menguatkan keyakinan bahwa Gulaku adalah merek gula pasir yang bercitra merek baik.

\section{REFERENCES}

Aaker, David. A \&Joachimsthaler, Erich.2000.Brand Leadership, New York : The Free Press.

Aaker, David. A. 1997. Manajemen Ekuitas Merek (ArisAnanda, Penerjemah). Jakarta : Penerbit Spektrum Mitra Utama.

Aaker, David. A. 1996.Measuring Brand Equity Across Product and Markets. New York : The Free Press.

Aaker, David. A .1991.Managing Brand Equity : Capitalization on the Value of a Brand Name. New York: The Free Press.

Arikunto, Suharsimi (1998) Prosedur Penelitian, Edisi Keempat.Jakarta :PenerbitRineka Cipta.

ChiengFayrene Y.L., Goi Chai Lee. 2011. Customer-Based Brand Equity: A Literature Review, Researches World, Journal Of Arts Science \& Commerce.

Direktorat Pangan Dan Pertanian Kementerian Perencanaan Pembangunan Nasional/ Badan Perencanaan Pembangunan Nasional. 2013.Rencana Pembangunan Jangka Menengah Nasional (RPJMN) Bidang Pangan Dan Pertanian 2015-2019

Fadli Dan InnekeQamariah.2008.Analisis Pengaruh Faktor-Faktor Ekuitas Merek Sepeda Motor Merek Honda Terhadap Keputusan Pembelian (Studi Kasus Pada Universitas Sumatera Utara), jurnalManajemen Bisnis, Volume 1 no. 2

Hair, Joseph F at all.2010.Multivariate Data Analysis "A Global Perspective " New Jersey : Pearson 
Hamka.2012. Analisis Ekuitas Merek Kecap Di Kota Ternate.Jurnal Agribisnis Kepulauan Volume 1 No. 1.

Keller, Kevin Lane .2013.Strategic Brand Management : Building, Measuring and Managing Brand Equity. England :Pearson.

Knapp, Duane E. 2000.The Brand Mindset( Drs. Sisnuhadi, MBA, Penerjemah ), Yogyakarta : Andi Offset

Kotler, Philip. 2008.New Strategic Brand Management : Creating and Sustaining Brand Equity Long Term.USA: Saxon Graphics Ltd.

Kotler, Philip. 2003. Marketing Management. New Jersey : Pearson.

Rosenbaum-elliot, Percy Larry, Pervan Simon.2011.Strategic Brand Management.New York :Oxford University Press Inc.

Malhotra, Naresh K. 2007. Marketing Research : An Applied Orientation, New Jersey: Pearson.

Melina Hermawan , Indah Victoria S. , BaniFebruarso. 2005.Analisis Pengukuran ElemenElemen Ekuitas Merek Ponsel Samsung Sebagai Usulan Untuk Mempertahankan Dan Meningkatkan Pangsa Pasar (Studi Kasus Ponsel Merek Samsung Di Kota Bandung.

Pappu, Ravi ; Quester, Pascale G; Cooksey, Ray W .2005.Consumer-Based Brand Equity: Improving The Measurement - Empirical Evidence. The Journal Of Product And Brand Management.

Rangkuti, Freddy .2002.The Power of Brands ( Teknik Mengelola Brand Equity dan Strategi Pengembangan Merek). Jakarta: PT. Gramedia Pustaka Utama.

Sugiyono.2004.Metode Penelitian Bisnis.Jakarta :Penerbit CV. Alfabeta.

Susanto , A.B \&Wijanarko, Himawan.2004 . Power Branding.Bandung : Penerbit Mizan

Tjiptono, Fandy.2005.Brand Management \&Strategi.Yogyakarta :Penerbit Andi Offset 